\title{
FIRST RECORD OF THE KING EIDER IN SASKATCHEWAN
}

ALAN R. SMITH, 614 Lansdowne Avenue, Saskatoon, Saskatchewan. S7N 1E3

Saskatchewan and Alberta are the only landlocked provinces in Canada, therefore occurrences of seafaring birds in either of these provinces might be considered unusual. It is so unusual for the King Eider that it has happened only once in each province: on 4 November 1894 an immature male was shot near Calgary, Alberta. It was accompanied by another bird that may have been an adult male. ${ }^{4}$ Eighty-nine years later a female-like bird appeared at Blackstrap Lake, Saskatchewan.

On 26 October 1983 I was birding at the south end of Blackstrap Lake. One of the first birds I saw was a large brown duck which, upon closer examination, I was astonished to discover was a King Eider. The identification was based partially on the standard field marks: the pattern of feathering at the base of the bill, and the profile. The clincher, however, was the head pattern: a conspicuous light line extended from the eye, down the neck, and around the nape in a ghostly suggestion of the head pattern of the adult male. (While many of the North American field guides show this field mark, none of the guides mention it in the text.)

Because I have seen both Common and King Eiders of both sexes in the Canadian Arctic, and because I saw this bird as close as $5 \mathrm{~m}, 1$ was convinced my identification was correct. But I also knew a specimen or photograph was necessary to place the species on the Saskatchewan list. I immediately phoned Bernie Gollop and Chris Escott in Saskatoon and asked them to bring their cameras along to provide photographic documentation. By the end of the day Brian Johns, Jim 
Wedgwood, Gollop and Escott of Saskatoon, and Guy and Robert Wapple of Biggar had seen the bird. Over the next 3 days the bird was seen by several more observers including Brenda Dale of Saskatoon, Chris Adam, Frank Brazier, Robert Kreba and John Triffo of Regina. Gollop, Johns, Escott and Kreba obtained photographs showing one or more of the diagnostic features. The bird was not seen again until 7 November when it reappeared at the Thode Townsite about $7 \mathrm{~km}$ northeast of the original sighting. It remained there until the final sighting on 18 November. Five days later Blackstrap Lake was frozen.

Although the photographs prove that the bird was a King Eider, I was initially confused as to its age and sex. I later concluded that because the base of the upper mandible was orange it was a first-year immature male. ${ }^{13}$ It will be another two years before this bird assumes the full adult male plumage. ${ }^{1}$

It is difficult to explain the occurrence of the King Eider on the prairies. The species breeds in the arctic, migrates coastally, and spends the winter at sea off the Aleutians, southwest Greenland or Atlantic Canada. ${ }^{2}{ }^{3}$
Indeed the nearest point of regula occurrence is $1000 \mathrm{~km}$ from Blackstra Lake on the Hudson Bay Coast c Manitoba. ${ }^{2}$ In referring to inland $r e$ cords of the King Eider in North Amer ica, Palmer speculated that if lingerin birds were forced to move (presumabl by inclement weather), they migh move more directly south; this woul take them into the interior. ${ }^{3}$ Whateve the explanation, let us hope we do no have to wait another 89 years for th next King Eider to appear!

${ }^{1}$ CRAMP, STANLEY, and K.E.L. SIMMONS eds. 1977. Handbook of the birds Europe, the Middle East, and Nort Africa: the birds of the Western Pale arctic. Vol 1: Ostrich to Ducks. Oxfor University Press, Oxford. 722 pp.

${ }^{2}$ GODFREY, W. EARL. 1966. The birds Canada. Nat. Mus. Canada Bull. 20 Ottawa. 428 pp.

3PALMER, RALPH S., ed. 1975. Handboo of North American birds. Vol. 3: Wate fowl (Part 2). Yale University Pres New Haven. 560 pp.

${ }^{4}$ SALT, W. RAY, and JIM R. SALT. 1976. Th birds of Alberta. Hurtig Publisher Edmonton. 498 pp.

\section{INTERNATIONAL ORNITHOLOGICAL CONGRESS}

The XIX International Ornithological Congress will take place in Ottawa, Cana from 22 to 29 June 1986. Prof Dr. Klaus Immelmann (West Germany) is Presid and Dr. Henri Ouellet (Canada) is Secretary General. The programme is bei planned by an international Scientific Programme Committee chaired by Profes: J. Bruce Falls (Canada). The programme will include plenary lectures, sympos contributed papers (spoken and posters), and films. There will be a mid-congre free day. Pre and post-congress excursions and workshops are planned in varic interesting ornithological regions of Canada.

Information and requests for application forms should be addressed to: Dr. Henri Ouellet, Secretary General, XIX Congressus Internationalis Ornitho gicus, National Museum of Natural Sciences, Ottawa, Ontario, Canada. K1A ON 